\title{
Effects of Seasonal Variations in Physical Parameters on Quality of Gravity Flow Water in Kyanamira Sub-County, Kabale District, Uganda
}

\author{
Hannington Ngabirano1, Denis Byamugisha², Emmanuel Ntambi ${ }^{2}$ \\ ${ }^{1}$ Department of Chemistry, Kabale University, Kabale, Uganda \\ ${ }^{2}$ Department of Chemistry, Mbarara University of Science and Technology, Mbarara, Uganda \\ Email: ngabiranoh@gmail.com
}

How to cite this paper: Ngabirano, H., Byamugisha, D. and Ntambi, E. (2016) Effects of Seasonal Variations in Physical Parameters on Quality of Gravity Flow Water in Kyanamira Sub-County, Kabale District, Uganda. Journal of Water Resource and Protection, 8, 1297-1309. http://dx.doi.org/10.4236/jwarp.2016.813099

Received: October 3, 2016

Accepted: December 20, 2016

Published: December 23, 2016

Copyright $\odot 2016$ by authors and Scientific Research Publishing Inc. This work is licensed under the Creative Commons Attribution International License (CC BY 4.0).

http://creativecommons.org/licenses/by/4.0/ (c) (i) Open Access

\section{Abstract}

The effect of seasonal variations in physical parameters on quality of gravity flow water was investigated in Kyanamira Sub-County, Kabale District, Uganda. The seasonal variations in the physical parameters $(\mathrm{pH}$, temperature, electrical conductivity (EC), turbidity, colour, total dissolved solids (TDS), and total suspended solids (TSS)) were determined during wet and dry seasons. Composite samples from gravity flow water sources were collected monthly from March to August, 2014 and then analyzed. Temperature was measured using thermometer; $\mathrm{pH}, \mathrm{EC}$ and TDS were determined using a multimeter, turbidity, colour and total suspended solids were determined by spectrophotometric method. TDS, $\mathrm{pH}$ and temperature were the most contributing parameters to water quality variations in both seasons. The mean $\mathrm{pH}$ values varied between 3.78 - 4.84 from March to August, 2014 at all study sites. These $\mathrm{pH}$ values were consistently below the WHO permissible range of 6.5 - 8.5. Similarly, total suspended solids varied between $0.66-2.17 \mathrm{mg} \cdot \mathrm{L}^{-1}$ and were well above the recommended WHO limit of zero $\mathrm{mg} \cdot \mathrm{L}^{-1}$ at all study sites. Turbidity mean values varied between 0.83 - 3.7 NTU and were outside the recommended limits of 3 NTU at Kigata (3.7 NTU) only. Temperatures $\left(20.3^{\circ} \mathrm{C}-21.15^{\circ} \mathrm{C}\right)$ for all the study sites were within the recommended limit of $20^{\circ} \mathrm{C}-30^{\circ} \mathrm{C}$ in water for domestic purposes. The mean values of physical parameters for the wet season were: temperature $\left(21.12^{\circ} \mathrm{C}\right)$, colour (12.5 PtCoU), turbidity (3.4 NTU), TDS (76.76 mg. $\left.\mathrm{L}^{-1}\right)$, TSS $\left(2.13 \mathrm{mg} \cdot \mathrm{L}^{-1}\right), \mathrm{pH}$ (4.19) and EC $\left(152.7 \mu \mathrm{S} \cdot \mathrm{cm}^{-1}\right)$ were different from those of the dry season (temperature $\left(20.99^{\circ} \mathrm{C}\right)$, colour $(0.93 \mathrm{PtCoU})$, turbidity (0.53 NTU), TDS $\left(77.33 \mathrm{mg} \cdot \mathrm{L}^{-1}\right)$, TSS $\left(0.67 \mathrm{mg} \cdot \mathrm{L}^{-1}\right), \mathrm{pH}(4.86)$ and $\mathrm{EC}\left(158.65 \mu \mathrm{S} \cdot \mathrm{cm}^{-1}\right)$. Basing on these findings above, it was evident to justify discouraging the use of gravity flow water at these study sites for domestic purposes without proper treatment. 


\section{Keywords}

Kyanamira Sub-County, Seasonal Variations, Gravity Flow Water, Physical Parameters

\section{Introduction}

Water is second to oxygen as being essential for life. People can survive days, weeks, or even longer without food, but only about four days without water (Nagarnaik and Patil, 2012) [1]. Groundwater is found in weathered portions, along the joints and fractures of the rocks (Rajappa et al., 2011) [2]. Gravity flow water mainly depends on groundwater which in turn depends on quality of recharged water, atmospheric precipitation, inland surface water and sub-surface geochemical processes. This implies that same factors which influence groundwater quality such as seasonal changes, geology, mineralisation in soil and rocks, agricultural land use, etc. influence gravity flow water quality in addition to materials used in construction of the gravity flow water system. It is therefore recommended that rural groundwater developers should make exploitation of good water quality a top priority as provision of polluted water will be counterproductive with all its attendant health hazards (Ocheri \& Egahi, 2013) [3].

Globally, groundwater provides about $50 \%$ of the current potable water supplies, $40 \%$ of the demand of self-supplied industry and $20 \%$ of water use in irrigated agriculture according to UNESCO (2003) estimate. Groundwater is the earth's largest accessible store of fresh water and excluding ice sheets and glaciers has been estimated to account for $94 \%$ of all fresh water (Ocheri \& Egahi, 2013) [3].

Groundwater provides more than $40 \%$ of California's drinking water. To protect this vital resource, the State of California created the Groundwater Ambient Monitoring and Assessment (GAMA) Programme. GAMA's priority basin project evaluates the quality of untreated groundwater in the Indian wells valley of California (Dawson and Kenneth, 2012) [4]. Groundwater provided $80 \%$ or more of the water supply in Uganda, especially in the rural areas. Uganda has a total area of 241,500 Sq. Km. Out of this, $15.3 \%$ is open water, $3.0 \%$ permanent wetlands and $9.4 \%$ seasonal wetlands and over 162 freshwater lakes and numerous rivers. Kabale district local government estimates show that gravity flow water supplies $50.2 \%$ of the population in the whole district (Danert et al., 2001) [5].

The demand of fresh water for the rapidly growing population in Kabale District is increasing as it is the case for the whole Uganda. The main source of water for drinking, domestic, agricultural and industrial activities in Kabale District is groundwater supplied via gravity flow water pipes. In the wet season, it was evident that the quality of water was poor as the gravity flow water emerged with its colour greatly changed. Observed human practices such as construction of deep pit latrines, use of agrochemicals, haphazard land usage, inappropriate waste disposal, among others threaten the quality of groundwater. In addition, petroleum products, construction materials, automobile 
fumes, leakages, etc. may infiltrate the groundwater aquifers contaminating them. There is no or paucity of data regarding the quality of the gravity flow water used in Kabale district in terms of physical parameters. It is thus timely to investigate seasonal variations in quality of gravity flow water used by the people in Kabale district, as it indirectly reveals the prevailing status of groundwater.

Seasonal changes enhance the effects of human practices and natural processes on gravity flow water quality through:

- Adsorption and desorption processes;

- Eutrophication of eroded organic matter;

- Dissolution, transportation and deposition of materials e.g. agrochemicals;

- Overflows or seepages from compost pits, pit latrines, etc.;

- Changing and/or interactions between water quality factors especially during the wet season.

What is lacking?

There is paucity of data regarding the quality of the gravity flow water used in Kabale district and perhaps elsewhere in Uganda. Besides, no water quality monitoring program for identifying and tracking periodic water quality changes is in place.

The effect of seasonal variations in physical parameters on quality of gravity flow water in the study sites (Kigata, Kihanga, Kacuro, Kitibya and Kanjobe) located in Kyanamira Sub-County; Kabale District, Uganda was studied. The study involved determining the variations in physical parameters of the water during the dry (MarchMay) and wet (June-August) seasons in 2014. The study was principally qualitative in terms quantitative analysis of physical parameters of gravity flow water in the study sites during dry and wet seasons. This study generated baseline data regarding the effect of seasonal variations in physical parameters on quality of gravity flow water used for domestic and agriculture purposes in Kabale District, Uganda.

\section{Materials and Methods}

\subsection{Study Area}

The water samples were collected from five study sites: Kigata, Kihanga, Kacuro, Kitibya and Kanjobe gravity flow water sources within $5 \mathrm{Km}$ distance from Kyanamira Sub-County headquarters located along old Kabale-Mbarara road in Kabale District, Uganda. The present investigation was to estimate the effect of seasonal variations in physical parameters on quality of gravity flow water from water sources located in Kyanamira sub-county, Kabale District, Uganda (Figure 1).

\subsection{Sample Collection}

Three sub-samples were collected from each gravity flow water source on a sampling day ( 1 day) per month. Composite samples from each gravity flow water source were obtained by mixing three sub-samples which were collected as follows: First sample from each source was obtained in the morning, second sample was obtained after midday and third sample was obtained in the evening followed by mixing the three 


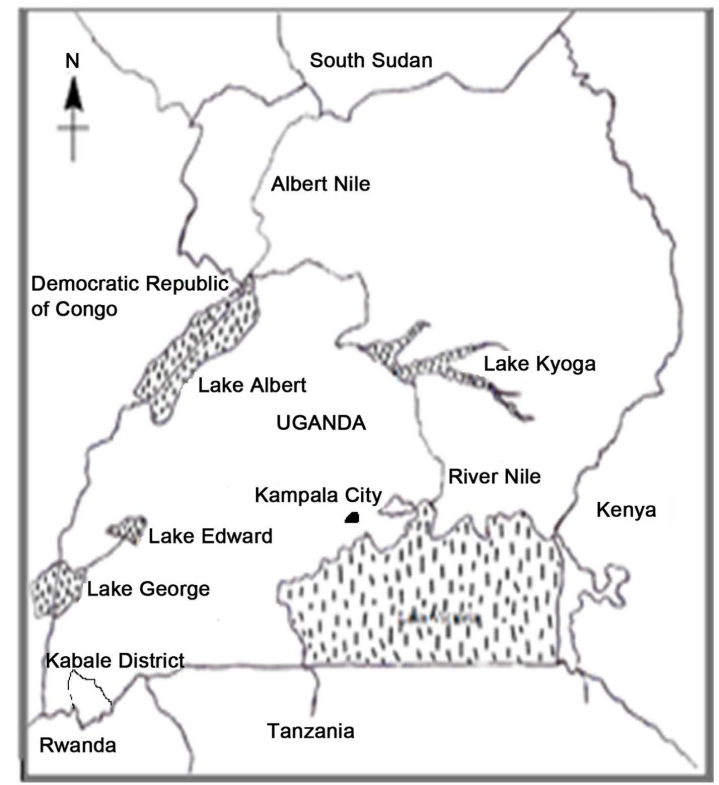

(a)

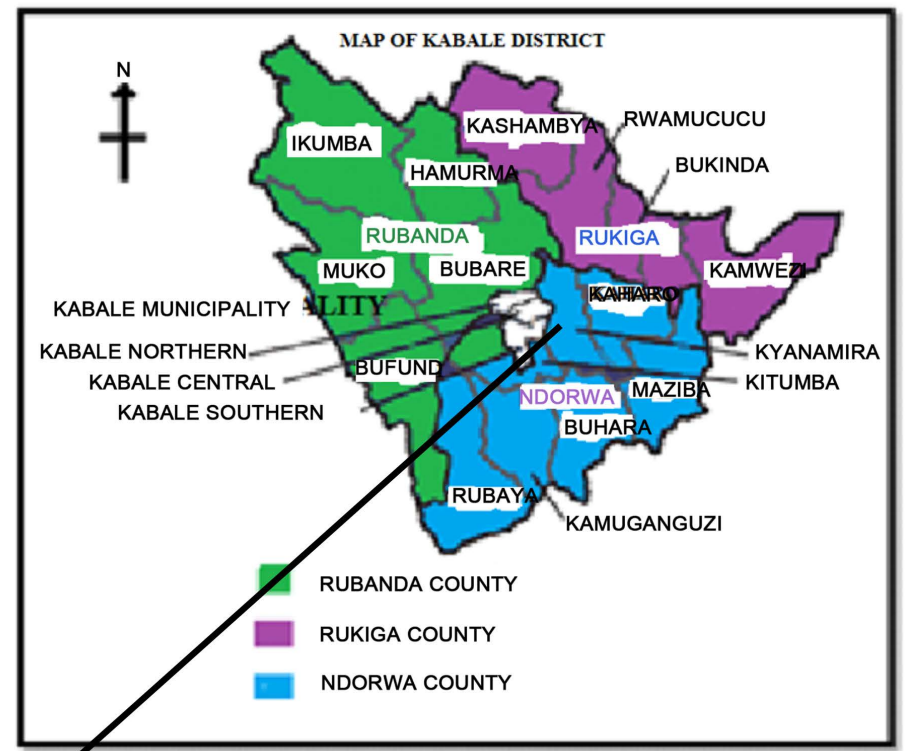

(b)

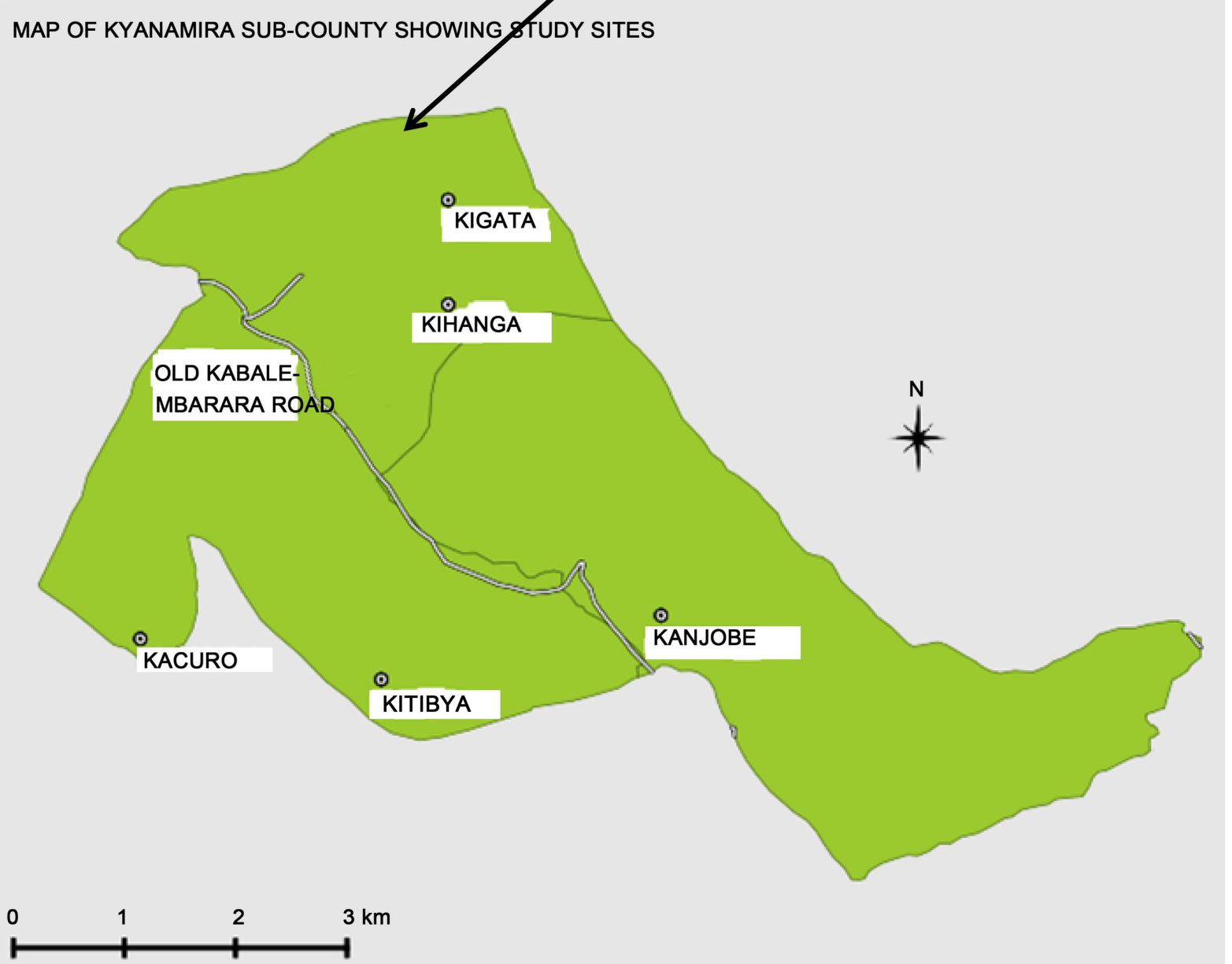

(c)

Figure 1. (a) Map of Uganda indicating the location of Kabale District; (b) Map of Kabale District indicating the location of Kyanamira sub-county; (c) Map of the study area. 
sub-samples from each source. These resulted into five composite samples obtained from the five gravity flow water sources. The samples were collected in the pre-cleaned plastic bottles with necessary precautions.

\subsection{Analysis}

Different analytical methods were used in determination of the physical parameters of gravity flow water quality in the samples obtained from the five different water tank reservoirs for a period of six months. The study assessed seasonal variations in temperature, $\mathrm{pH}$, colour, turbidity, total suspended solids, electrical conductivity and total dissolved solids mean values. The mean values of $\mathrm{pH}$, temperature, TDS and EC of the samples were noted at the sampling sites. Colour, TSS and turbidity were determined by spectrophotometry following standard procedures including calibrations. The results were compared with recommended standard limits for drinking water quality parameters.

Temperature measurements, $\mathrm{pH}$ and electrical conductivity were taken by dipping a multi-meter probe into the water samples on each study site and calculated their mean values for each sample per day per month. Turbidity, colour, total dissolved solids and total suspended solids were determined using spectrophotometric method.

\section{Results and Discussion}

The quality of gravity flow water was determined in terms of the mean values of physical parameters which were compared with their WHO recommended limits for proper functioning of the biological systems of human beings.

\subsection{Temperature}

There was a general increase in temperature values which ranged between $19^{\circ} \mathrm{C}$ to $22.4^{\circ} \mathrm{C}$ from March to August, 2014. Temperature was high in June, July and August in most study sites. The highest temperature $\left(22.8^{\circ} \mathrm{C}\right)$ was registered at Kitibya in June, followed by $22.5^{\circ} \mathrm{C}$ at the same water source during August, 2014 .

The lowest mean temperature values between $19^{\circ} \mathrm{C}$ and $21^{\circ} \mathrm{C}$ were recorded in March, 2014 at all study sites (see Figure 2). Temperature changes affect $\mathrm{pH}$, sorption processes, complexation, speciation, precipitation, redox reactions, flow rate, ion exchange capacity, solubility of gases and/or other compounds, electrical conductivity just to mention but a few. Temperature changes of only 5 to $10^{\circ} \mathrm{C}$ in gravity flow water may cause detectable changes in TDS values. Increase in temperature increases electrical conductivity. Also, increase in temperature decreases the amount of dissolved oxygen, accelerates nitrification and oxidation of ammonia to nitrates (III) and (V) leading to oxygen deficient water environment. This increases toxicity of pesticides and heavy metals in drinking water.

Temperature increase in drinking water leads to a less palatable water taste. Temperatures in gravity flow water samples varied between $19^{\circ} \mathrm{C}$ to $22.8^{\circ} \mathrm{C}$ and were well below the recommended limit of $20^{\circ} \mathrm{C}-30^{\circ} \mathrm{C}$ for drinking water. Variations in temperature 


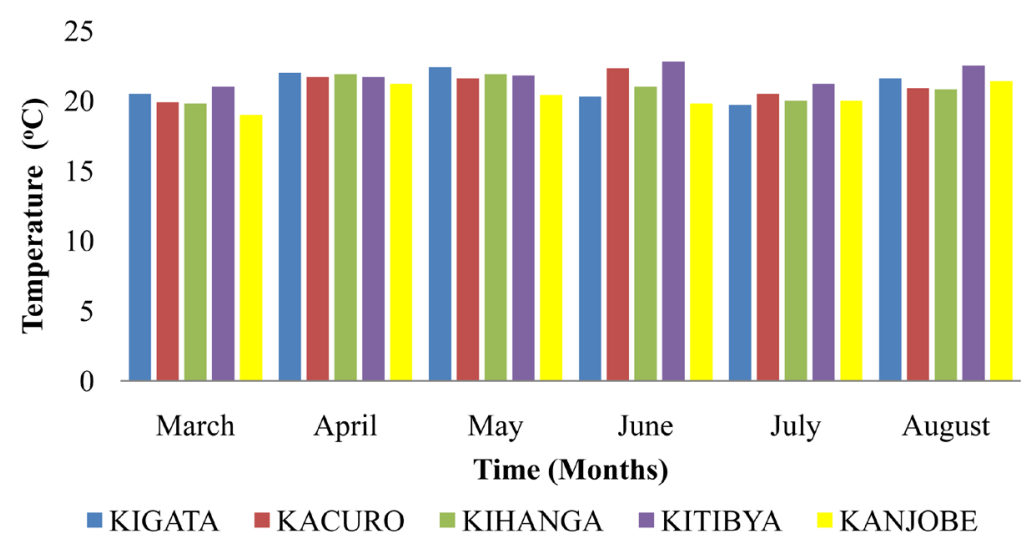

Figure 2. Mean temperature values from March to August, 2014.

were attributed to seasonal changes, depth of gravity flow water sources, different timing of sample collection and mixing with air whether cold or warm from the surrounding rocks and soils in the plumes.

\subsection{Colour}

Generally, higher mean colour values were noticed during the wet season (MarchApril) as compared to the dry season (June-August), 2014. Kigata (37 PtCoU) and Kitibya (34 PtCoU) registered the highest mean colour values during March and April (wet season), respectively. However, most of the study sites recorded zero mean colour value during the dry season. The highest mean colour value (7 PtCoU) recorded during the dry season was more than 5 times lower than the highest mean colour value (37 $\mathrm{PtCoU}$ ) recorded during the wet season.

The higher mean colour values during the wet season were attributed to the presence of precipitates, metal complexes/chelates and adsorption of coloured water constituents on dissolved humic substances. Small clay mineral particles and colloids also increase the colour of gravity flow water, in addition to the coloured compounds of iron and manganese. High colour values may be due to turbidity resulting from the coagulation of organic matter present in the gravity flow water. Also, because of soil erosion fine soil particles may enter gravity flow water sources and hence affect its colour values. During the dry season, the mean colour values were low implying that small clay mineral particles, colloids, turbidity, precipitates and metal complexes were at low concentrations in the gravity flow water samples. The study sites indicated zero values (0 PtCoU) for colour during May except Kanjobe which recorded 7 PtCoU (see Figure $3)$.

\subsection{Turbidity}

Mean turbidity values recorded gave an overview of the variations in gravity flow water quality during wet and dry seasons. The highest mean turbidity value (13 NTU) was observed in the wet season (March) at Kigata. This was due to high concentrations of small clay mineral particles, dissolved coloured compounds and colloids. In March and 


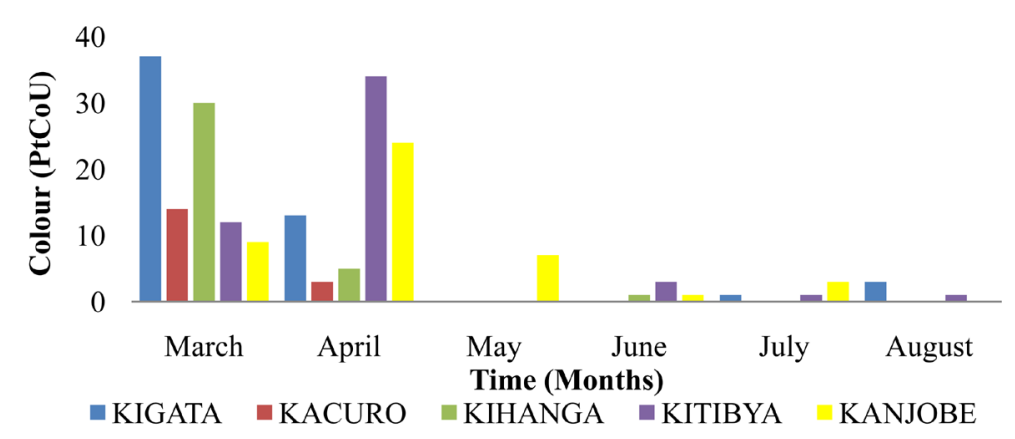

Figure 3. Mean colour values from March to August, 2014.

April, most of the study sites had mean turbidity values well above the allowable WHO limit ( $3 \mathrm{NTU}$ ). The lowest mean turbidity value (0 NTU) was observed at various study sites in the dry season beginning with May to August, 2014. All the study sites recorded (0 NTU) except Kigata which had (1 NTU) in July, 2014 (see Figure 4). This was because of the reduction in runoff material, precipitates, chelates, suspended solids and coloured dissolved substances during the dry season which contributed to turbidity.

Colour and turbidity seemed to follow the same trends both decreasing from wet to dry season. Coloured dissolved compounds, precipitates, chelates; small clay mineral particles and colloids were responsible for the high and low mean turbidity values in the wet and dry seasons, respectively. During the dry season (from May to August) mean turbidity values were within the permissible WHO limits for all study sites. Turbidity values recorded during the study ranged between 0.83 and 3.7 NTU. The maximum turbidity value was registered at Kigata (3.7 NTU) with the minimum turbidity value being recorded at Kacuro (0.83 NTU).

The mean turbidity value at Kigata was above the WHO allowable limit. The high turbidity values observed during the wet season in the study may have been due to coagulation of dissolved substances in the water reservoirs. Particles from weathering activities in the underground waterways and surface runoff from agricultural fields around the gravity flow water sources also contribute to turbidity.

\subsection{Total Dissolved Solids (TDS)}

The mean concentrations of total dissolved solids (TDS) are an important parameter in gravity flow water. Findings of the study indicated that the mean total dissolved solids varied appreciably at all study sites from March to August, 2014 (see Figure 5). The highest mean TDS value was measured in the dry season (August) in Kigata (146.8 $\mathrm{mg} \cdot \mathrm{L}^{-1}$ ) and it was observed that Kigata registered the highest mean TDS values throughout the period of the study.

Kitibya recorded TDS mean values in a range of $43.5-46.3 \mathrm{mg} \cdot \mathrm{L}^{-1}$ throughout the period of the study. This could have been due to the higher temperatures observed during the dry season which facilitated dissolution, ion exchange capacity, desorption and weathering processes. Also, during the dry season water evaporated and ion concentrations increased. 


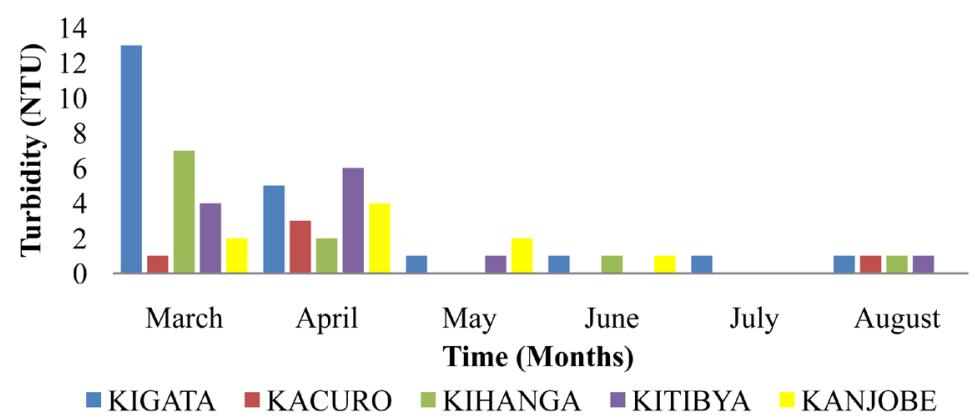

Figure 4. Mean turbidity values from March to August, 2014.

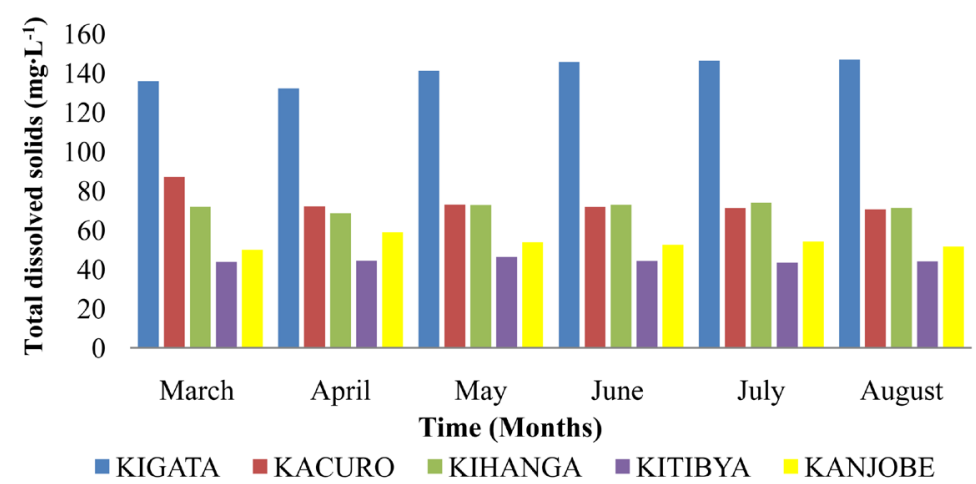

Figure 5. Mean TDS values from March to August, 2014.

TDS values in gravity flow water originate from natural sources, deep pit latrines, construction sites and agricultural activities. The values of the total dissolved solids for all the gravity flow water samples varied between 44.38 and $141.3 \mathrm{mg} \cdot \mathrm{L}^{-1}$. The allowable limit of total dissolved solids in water for domestic purpose is $1000 \mathrm{mg} \cdot \mathrm{L}^{-1}$. The maximum value was recorded at Kigata $\left(141.3 \mathrm{mg} \cdot \mathrm{L}^{-1}\right)$ and minimum value was recorded at Kitibya $\left(44.38 \mathrm{mg} \cdot \mathrm{L}^{-1}\right)$. According to classification of drinking water on the basis of TDS values, all the gravity flow water samples were found to be non-saline and well within the permissible limit of $1500 \mathrm{mg} \cdot \mathrm{L}^{-1}$ (see Table 1 ).

The fluctuations in temperatures of gravity flow water from March to August, 2014, did not influence mean TDS values which generally increased from the wet to the dry season. This was due to low and high evaporation rates in the wet and dry seasons, respectively. Concentrations of dissolved constituents in gravity flow water are not temperature dependent, i.e. the correlation coefficient was negative $(-0.059)$ and very weak (see Figure 6).

\subsection{Total Suspended Solids (TSS)}

The total suspended solids (TSS) generally decreased from the wet season (MarchApril) to the dry season (May-August). The highest mean TSS value was observed in the wet season (March) at Kigata $\left(8 \mathrm{mg} \cdot \mathrm{L}^{-1}\right)$ followed by dramatic decreases in TSS values to as low as $0 \mathrm{mg} \cdot \mathrm{L}^{-1}$ at various study sites through April to August (see Figure 7). In March, mean TSS values were above the permissible WHO limits $\left(0 \mathrm{mg} \cdot \mathrm{L}^{-1}\right)$ for all 


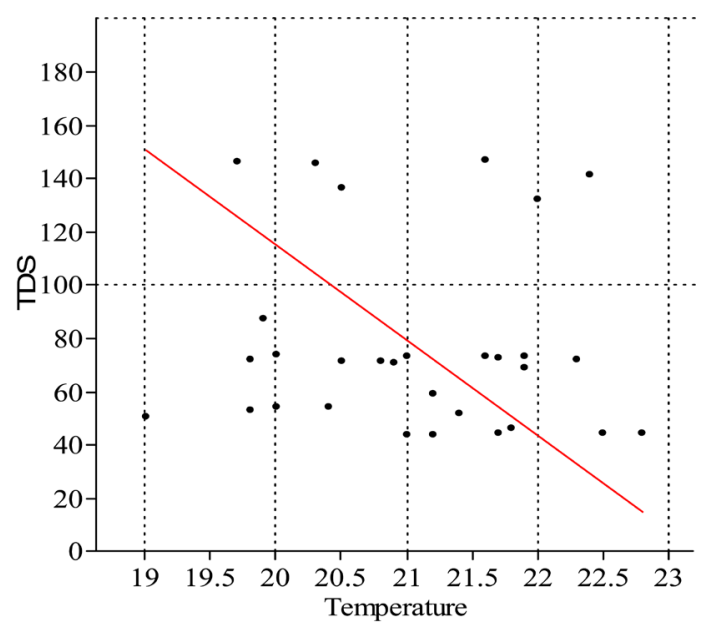

Figure 6. Variation of TDS with temperature values from March to August, 2014.

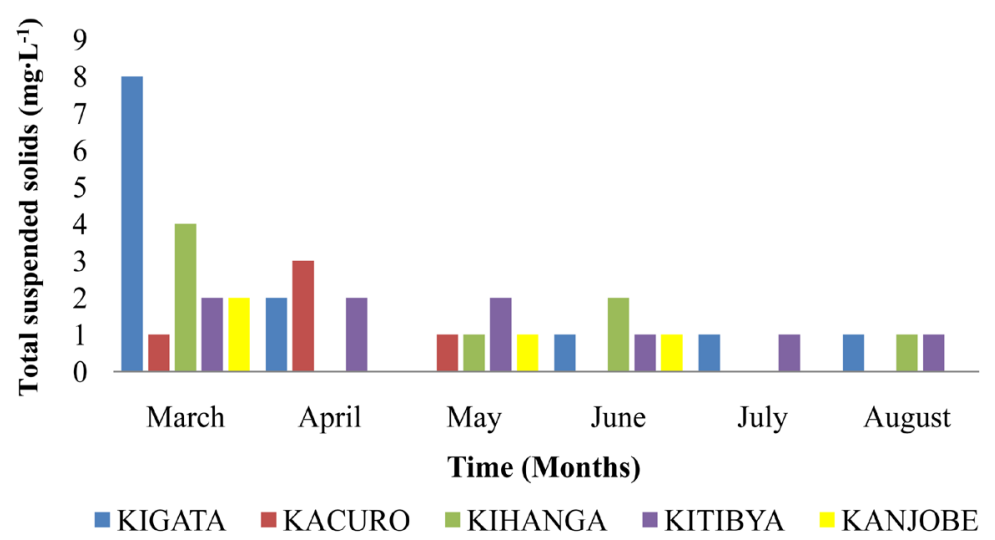

Figure 7. Mean TSS values from March to August, 2014.

Table 1. Relationship between TDS and temperature.

\begin{tabular}{ccccccccccc}
\hline \multirow{2}{*}{ Study } & \multicolumn{2}{c}{ KIGATA } & \multicolumn{2}{c}{ KACURO } & \multicolumn{2}{c}{ KIHANGA } & \multicolumn{2}{c}{ KITIBYA } & \multicolumn{2}{c}{ KANJOBE } \\
\cline { 2 - 10 } & $\begin{array}{c}\text { Temp } \\
/{ }^{\circ} \mathrm{C}\end{array}$ & $\begin{array}{c}\mathrm{TDS} \\
/ \mathrm{mg} \cdot \mathrm{L}^{-1}\end{array}$ & $\begin{array}{c}\mathrm{Temp} \\
/{ }^{\circ} \mathrm{C}\end{array}$ & $\begin{array}{c}\mathrm{TDS} \\
/ \mathrm{mg}_{\mathrm{L}} \mathrm{L}^{-1}\end{array}$ & $\begin{array}{c}\mathrm{Temp} \\
/{ }^{\circ} \mathrm{C}\end{array}$ & $\begin{array}{c}\mathrm{TDS} \\
/ \mathrm{mg} \cdot \mathrm{L}^{-1}\end{array}$ & $\begin{array}{c}\mathrm{Temp} \\
/{ }^{\circ} \mathrm{C}\end{array}$ & $\begin{array}{c}\text { TDS } \\
/ \mathrm{mg} \cdot \mathrm{L}^{-1}\end{array}$ & $\begin{array}{c}\mathrm{Temp} \\
/{ }^{\circ} \mathrm{C}\end{array}$ & $\begin{array}{c}\mathrm{TDS} \\
/ \mathrm{mg} \cdot \mathrm{L}^{-1}\end{array}$ \\
\hline March & 20.5 & 135.9 & 19.9 & 87.1 & 19.8 & 71.8 & 21.0 & 43.8 & 19.0 & 50.0 \\
April & 22.0 & 132.1 & 21.7 & 72.1 & 21.9 & 68.5 & 21.7 & 44.4 & 21.2 & 58.8 \\
May & 22.4 & 141.2 & 21.6 & 72.9 & 21.9 & 72.7 & 21.8 & 46.3 & 20.4 & 53.8 \\
June & 20.3 & 145.6 & 22.3 & 71.7 & 21.0 & 72.8 & 22.8 & 44.3 & 19.8 & 52.5 \\
July & 19.7 & 146.2 & 20.5 & 71.2 & 20.0 & 73.9 & 21.2 & 43.5 & 20.0 & 54.2 \\
August & 21.6 & 146.8 & 20.9 & 70.5 & 20.8 & 71.3 & 22.5 & 44.0 & 21.4 & 51.5 \\
\hline
\end{tabular}

study sites. The TSS values in gravity flow water samples varied between 0.66 and 2.17 $\mathrm{mg} \cdot \mathrm{L}^{-1}$. The maximum mean TSS value was observed at Kigata while the minimum mean TSS value was recorded at Kanjobe. The mean TSS values of gravity flow water 
samples were above the allowable WHO TSS value of zero mg. $\mathrm{L}^{-1}$ in all study sites. Total suspended solids may have been due to changes in season, $\mathrm{pH}$ and temperature affecting weathering processes, formation of complex compounds, coagulation and sorption processes occurring in the gravity flow water sources.

Also, presence of organic matter particles from leaching activities may enter groundwater that feeds gravity flow water sources considered in the study contributing to total suspended solids. The trends in variations of colour, total suspended solids and turbidity look almost similar implying that total suspended solids contributed to the high mean values of colour and turbidity during the wet season. Total suspended solids may transfer heat to water molecules increasing the temperature of the surrounding water.

\section{6. $\mathrm{pH}$}

There was a general increase in mean $\mathrm{pH}$ from wet season (March-April) to dry season (May-August) (see Figure 8). All mean $\mathrm{pH}$ values were outside the allowable WHO, (2015) standard limits $(6.5$ - 8.5) for all the samples during the period of the study (March-August, 2014). Kigata registered the lowest mean $\mathrm{pH}$ values throughout the period of study while Kanjobe recorded the highest mean $\mathrm{pH}$ values during the dry season (July-August). The figure below shows that Kacuro and Kihanga registered almost the same mean values of $\mathrm{pH}$ from April to August. However, as shown in Table 1 all the mean $\mathrm{pH}$ values measured at the study sites were in the acidic range $(\mathrm{pH}=3.8-4.8)$. The highest $\mathrm{pH}$ value was observed at Kitibya (4.8) and the lowest value was observed at Kigata (3.8). All the gravity flow water samples were found to be outside the acceptable WHO limit of pH between 6.5 - 8.5. The acidity may have been due to high carbon dioxide concentrations from eutrophication processes of organic matter, adsorption of metal anions and presence of some non-metallic compounds such as fluorides in the gravity flow water sources.

The low $\mathrm{pH}$ values were also attributed to lower temperature hence lower TDS values, higher precipitation and adsorption processes and lower ion exchange capacity taking place in gravity flow water. Since the gravity flow water samples were acidic, this water corrodes metallic equipment and facilitates dissolution and desorption processes.

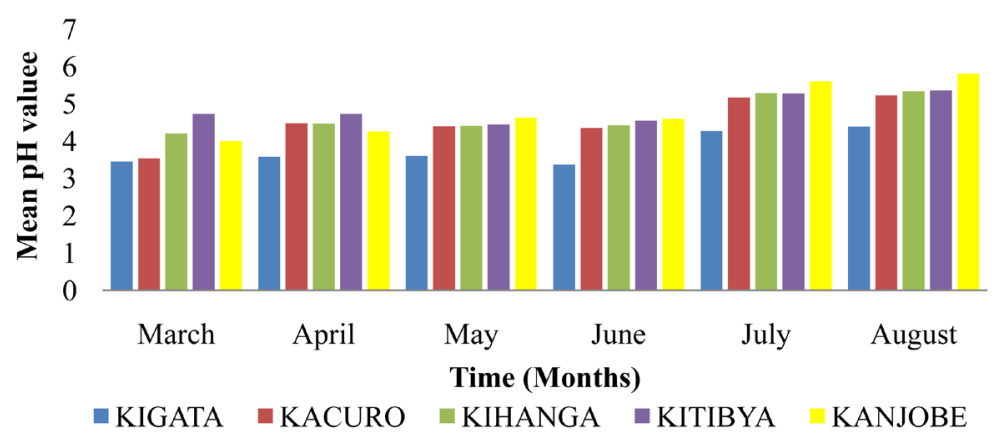

Figure 8. Mean pH values from March to August, 2014. 
In the study, it was observed that $\mathrm{pH}$ values increased with in dissolved oxygen. The low $\mathrm{pH}$ values which were common in the wet season are attributed to the anaerobic conditions that could lead to the production of acidic substances such as organic acids. The mean values of $\mathrm{pH}$ and dissolved oxygen were found to be moderately correlated where $r=+0.438$ (see Figure 9).

\subsection{Electrical Conductivity}

Electrical conductivity (EC) values fluctuated with slight increase observed from March to August, 2014 at Kigata, Kacuro, Kihanga and Kitibya; then a decrease in EC was observed from April to August, 2014 at Kanjobe. The results revealed that Kigata had the highest mean EC values and Kitibya had the lowest mean EC values throughout the period of study. Kacuro and Kihanga study sites showed almost the same mean EC values especially from April to August, 2014. The highest mean value of EC $\left(164.4 \mu \mathrm{S} \cdot \mathrm{cm}^{-1}\right)$ was recorded during March at Kacuro (see Figure 10).

The EC values of gravity flow water in all study sites ranged between $93-281.8$ $\mu \mathrm{S} \cdot \mathrm{cm}^{-1}$ and the values were within the permissible WHO limit $\left(400 \mu \mathrm{S} \cdot \mathrm{cm}^{-1}\right)$. Electrical

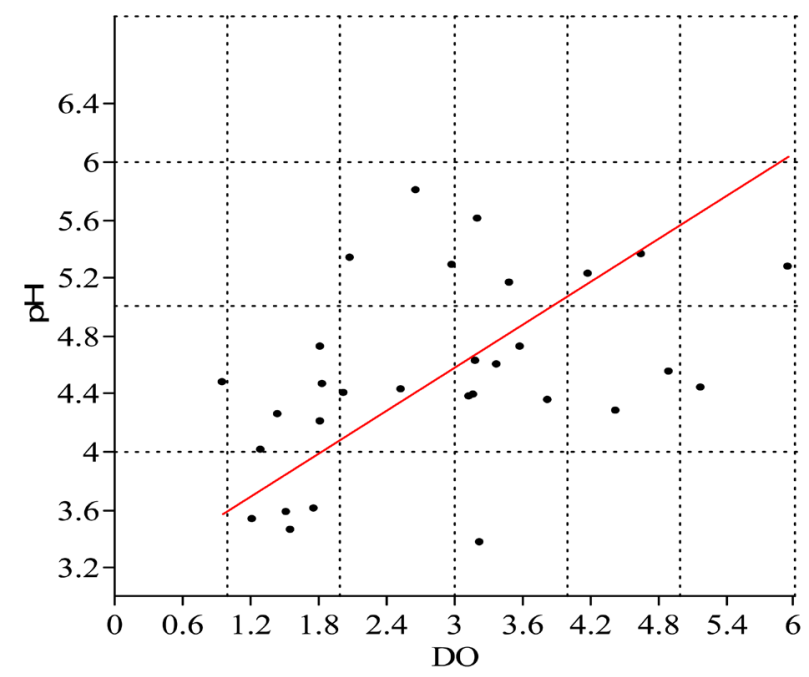

Figure 9. Variation of $\mathrm{pH}$ with $\mathrm{DO}$ values from March to August, 2014.

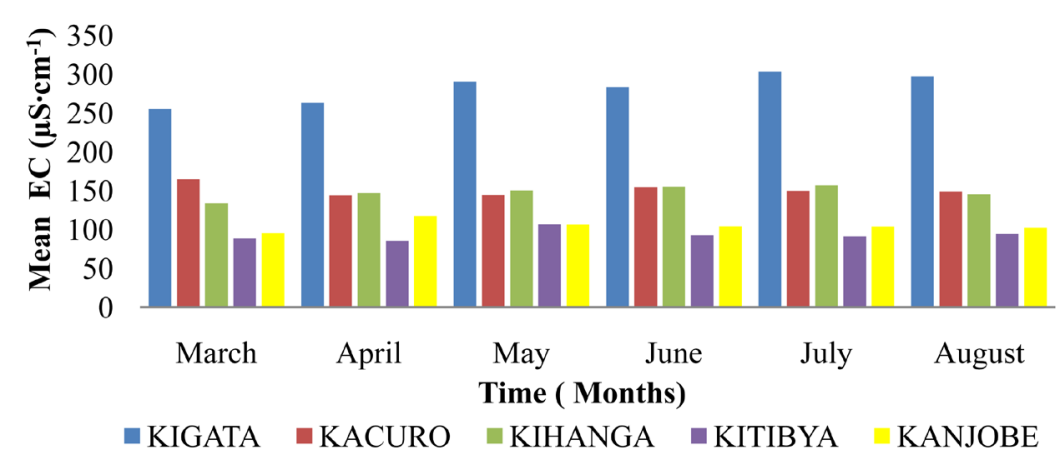

Figure 10. Mean EC values from March to August, 2014. 
conductivity increases with temperature since it increases ionic mobility. Electrical conductivity values provide a useful indicator for spatial and/or temporal changes in abstraction, salt water intrusion; recharge mechanism, etc. leading to different gravity flow water qualities in wet and dry seasons.

Water evaporates during the dry season and concentration of ions increases hence electrical conductivity increases. Likewise, in the wet season there is dilution of the ions due to rainwater increasing underground water volumes resulting in a decrease in electrical conductivity.

The study showed that EC values increased linearly with increasing TDS. TDS values were higher during dry season (June to August) in 2014. The increase in EC was due to evaporation of water in underground water channels which increased the concentrations of dissolved salts (conducting substances) in the gravity flow water systems. Also, low volumes of water flowing through the underground water plumes with higher velocities dissolve more salts from the rocks in contact with it. Electrical conductivity of the gravity flow water was strongly and positively correlated to total dissolved solids with a correlation coefficient value, $r=+0.99$ (see Figure 11).

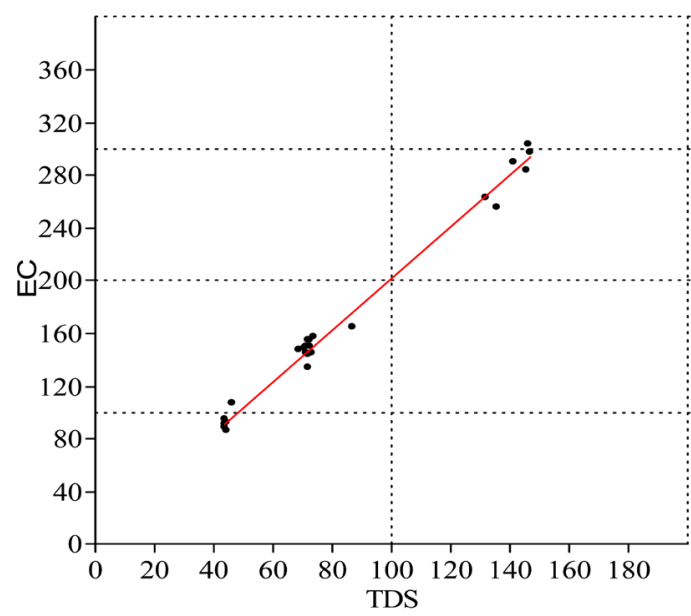

Figure 11. Variation of EC values with TDS from March to August, 2014.

Table 2. Mean parameter values recorded for each study site from March to August, 2014.

\begin{tabular}{cccccccc}
\hline Parameters & Units & Kigata & Kacuro & Kihanga & Kitibya & Kanjobe & WHO limits \\
\hline Temperature & ${ }^{\circ} \mathrm{C}$ & 21.00 & 21.15 & 20.9 .00 & 21.80 & 20.30 & Not specified \\
Colour & PtCoU & 9.0 & 2.8 & 6.0 & 8.5 & 7.3 & 15.0 \\
Turbidity & $\mathrm{NTU}$ & 3.70 & 0.83 & 1.83 & 1.83 & 1.50 & 3.00 \\
TDS & $\mathrm{mg} \cdot \mathrm{L}^{-1}$ & 141.30 & 74.25 & 71.83 & 44.38 & 53.47 & 1000.00 \\
TSS & $\mathrm{mg} \cdot \mathrm{L}^{-1}$ & 2.17 & 0.83 & 1.33 & 1.50 & 0.66 & 0.00 \\
$\mathrm{pH}$ & - & 3.78 & 4.52 & 4.68 & 4.84 & 4.81 & $6.5-8.5$ \\
$\mathrm{EC}$ & $\mu \mathrm{S} \cdot \mathrm{cm}^{-1}$ & 281.8 & 158.8 & 147.9 & 93 & 104.8 & 400
\end{tabular}


Gravity flow water quality deteriorates more in the wet season in Kyanamira subcounty, Kabale District, Uganda and therefore gravity flow water systems require special attention, as some of the important physical parameters such as $\mathrm{pH}$ and TSS are high (see Table 2). Since gravity flow water is diverted groundwater, the low mean $\mathrm{pH}$ values may affect the quality of gravity flow water especially in the wet season by influencing other water quality parameters such as heavy metal concentrations, pathogens, dissolved oxygen, hardness and alkalinity to mention but a few. Thus, it is important to discourage use of gravity flow water for domestic purposes without proper treatment.

\section{References}

[1] Nagarnaik, P.B. and Patil, P.N. (2012) Analysis of Ground Water of Rural Areas of Wardha-City Using Physico-Chemical and Biological Parameters. Groundwater Quality, 2, 803807.

[2] Rajappa, B., Manjappa, S., Puttaiah, E.T. and Nagarajappa, D.P. (2011) Physico-Chemical Analysis of Underground Water of Harihara Taluk of Davanagere District, Karnataka, India. Advances in Applied Science Research, 2, 143-150.

[3] Ocheri, M.I. and Egahi, M. (2013) Principal Component Analysis of Rural Groundwater Quality of Benue State, Nigeria. Journal of Environmental Hydrology, 21, 1-2.

[4] Dawson, B.J.M. and Belitz, K. (2012) Groundwater Quality in the Indian Wells Valley, California.

[5] Danert, K., Adekile, D. and Canuto, J.G. (2001) British Geological Survey; Groundwater quality: Uganda.

Submit or recommend next manuscript to SCIRP and we will provide best service for you:

Accepting pre-submission inquiries through Email, Facebook, LinkedIn, Twitter, etc.

A wide selection of journals (inclusive of 9 subjects, more than 200 journals)

Providing 24-hour high-quality service

User-friendly online submission system

Fair and swift peer-review system

Efficient typesetting and proofreading procedure

Display of the result of downloads and visits, as well as the number of cited articles

Maximum dissemination of your research work

Submit your manuscript at: http://papersubmission.scirp.org/

Or contact jwarp@scirp.org 